\title{
Reconstruction of fire history in Mexican tropical pines using tree rings
}

\author{
by Brooke A. Cassell ${ }^{1,2}$ and Ernesto Alvarado²
}

\begin{abstract}
A dendropyrochronological study was conducted in pine-dominated forest in the Sierra de Manantlán Biosphere Reserve located in the Sierra Madre del Sur mountain range in Mexico. Tropical pines present several difficulties for tree-ring research including missing, false and diffuse rings. This paper discusses the methods that were used to analyze tree rings in order to reconstruct fire history based on the dating of fire scars sampled from tropical pines.
\end{abstract}

Key words: fire history, dendrochronology, Sierra de Manantlán Biosphere Reserve, false rings

\section{RÉSUMÉ}

Une étude dendropyrochronologique a été effectuée dans un peuplement dominé par le pin dans la Réserve de la biosphère de la Sierra de Manantlán située dans la chaîne de montagnes de la Sierra Madre del Sur au Mexique. Les pins tropicaux présentent plusieurs difficultés pour létude des anneaux de croissance en raison d’anneaux absents et de la présence de faux anneaux et d'anneaux diffus. Cet article discute des méthodes qui ont été utilisées pour analyser les anneaux de croissance de façon à établir l'historique des feux à partir de la datation des cicatrices de feu relevées sur les pins tropicaux.

Mots clés : historique des feux, dendrochronologie, Réserve de la biosphère de la Sierra de Manantlán, faux anneaux

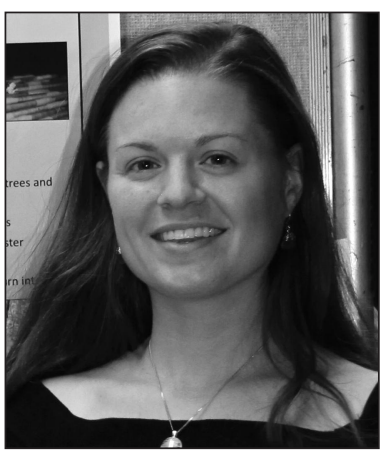

Brooke A. Cassell

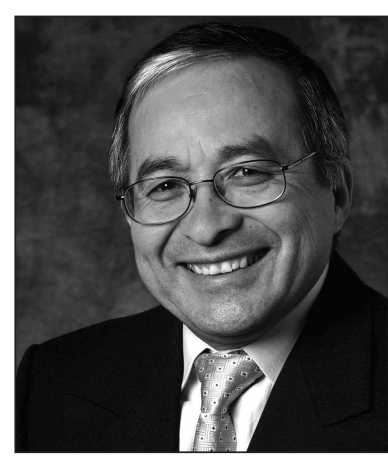

Ernesto Alvarado

\section{Introduction}

Fire is a natural process that plays a role in developing and maintaining ecosystems worldwide (Agee 1993, Whelan 1995). The frequency, extent, intensity and severity of fires in a given ecosystem can shape vegetation communities, and understanding fire in a historical context can not only help explain the development of an ecosystem but can provide scientific evidence to inform land management decisions into the future. Dendropyrochronology, or the study of assigning dates to historical fires through the use of tree-ring analysis, is the method most frequently employed when reconstructing fire histories in high-frequency, low-severity fire regimes such as are found in some pine-dominated forests (Speer 2010). Fire scars, distinctive curled-growth patterns resulting from annual ring growth following cambium death during extreme heating by fire, are analyzed and dated by determining the year of the annual ring in which they occur. The frequency and variability of fires is then computed over a given time period and area to characterize the historical frequency of fire (Agee 1993).

A dendropyrochronological study was conducted in the pine, pine-oak and pine-mixed broadleaf forests in the Sierra de Manantlán Biosphere Reserve (SMBR) in Jalisco and Colima, México. This study served several purposes: to determine the viability of Pinus douglasiana Martínez, the dominant tree species in the study site, for use in tree-ring studies; to create a master chronology of tree rings for use in this and future research; and to reconstruct the historical range of variation of fire frequency in these forests.

\section{Tree Rings in Tropical Pines}

Coniferous trees in seasonal climates form annual rings as they grow radially in size. These rings are variable in width depending on limiting growth factors such as temperature, water availability or between-tree competition (Fritts 1976). Annual rings are made up of earlywood, which is formed during the growing season and has relatively large tracheid cells with thin walls, and latewood, which is formed as availability of limiting factors such as temperature or moisture decreases causing cambial activity to slow and form smaller tracheid cells with thicker walls (Stokes and Smiley 1968, Fritts 1976). Crossdating is a technique used to match patterns of wide and narrow rings among trees, which can then be used to assign the correct calendar year to events such as drought, insect outbreak, fire and other disturbances in samples of both living and dead wood (Fritts 1976, Speer 2010). In climates that

\footnotetext{
${ }^{1}$ Corresponding author. E-mail: bcassell@uw.edu

${ }^{2}$ University of Washington, School of Environmental and Forest Sciences, Seattle, WA, USA.
} 
do not experience seasonal changes, annual rings do not always form, and when present they can differ in structure and appearance as compared to trees in seasonal climates. Crossdating cannot be used when patterns in annual rings cannot be determined (Stokes and Smiley 1968, Fritts 1976). However, in tropical climates where seasonal differences exist, even where those differences are not extreme, crossdating is possible as was shown by Huante $e t$ al. (1991) in sacred fir (Abies religiosa [Kunth] Schltdl. et Cham.) in Michoacán, Mexico.

Some of the difficulties in crossdating tropical tree rings are due to missing, false and diffuse rings. Missing rings occur when the limiting factors that trigger a slowing of growth, resulting in the formation of latewood, or the cessation of limiting factors that trigger growth, do not reach threshold levels resulting in the tree failing to produce an annual ring. They can also result from non-circular boles "pinching out" portions of rings so that they are missing in some portions of the tree's cross-section (Stokes and Smiley 1968). False rings can occur when there is a fluctuation in limiting factors, such as when a drought occurs during a growth season before the rains return or unseasonable rains occur during a dry season (Priya and Bhat 1998, Wimmer et al. 2000, Hoffer and Tardif 2009, Marchand and Filion 2012). False ring formation can also be triggered by environmental conditions (Priya and Bhat 1998, Copenheaver et al. 2006) or phenological causes (Edmondson 2010), but the causes of false ring formation in many species are still poorly understood. Diffuse rings are annual rings that do not have a distinct transition from late to earlywood, which can occur when trees are not subject to limiting factors during an entire year and at least one subsequent annual ring is difficult to discern from the previous ring (Speer 2010).

Detection of false, missing and diffuse rings is vital in crossdating. Several methods have been described for identification of false rings (see Stokes and Smiley 1968, Speer 2010) including observing the abruptness of the transition from late to earlywood, checking for radial files that contain a row of earlywood cells extending through the latewood as an indicator that the ring is false and observing whether resin ducts are contained within the latewood, as false latewood in some species will terminate at the duct. Missing and diffuse rings must be identified by crossdating multiple samples, and crossdating is often the only reliable method of detecting false rings in tropical pines where the above methods are not always viable.

\section{The Study Site}

The SMBR is 140000 hectares of protected land in the Sierra Madre del Sur mountain range in the states of Jalisco and Colima in western Mexico (Fig. 1). Established in 1987, its objectives include conservation of a mosaic of ecosystem types across the landscape including critical habitat for over 560

vertebrate species, including the endangered thick-billed parrot (Rhynchopsitta pachyrhyncha) and near-threatened jaguar (Panthera onca) and 2900 vascular plant species including the threatened Guatemalan fir (Abies guatemalensis Rehd.) (INE 2000). Fire has been noted as one of the most important factors in shaping this landscape despite the fact that fire ignitions are almost exclusively anthropogenic in nature (Jardel 1991, Jardel P. et al. 2003). Reliable fire records only extend back to 1995 when fire-fighting records became prioritized (Balcázar-Medina 2011) and previous fire records have relied upon first-hand observations by reserve managers and local community members as well as a small number of dated fire scars (Jardel 1991, Jardel-Peláez et al. in press).

The University of Guadalajara's Las Joyas Research Station (see ECLJ in Fig. 1 for the research station boundary) is a 1200 -hectare portion of the SMBR that is part of a core protected zone in the reserve. It ranges in elevation between 1560 and 2240 meters above sea level (masl), which encompasses most of the habitat range for Pinus douglasiana, the primary species used in the study.

\section{Research Methods}

Two field seasons were conducted in June-July, 2010 and January-February, 2011. A total of 15 plots were established for collection of tree cores and partial cross-sections of firescarred trees (Arno and Sneck 1977). Cores and cross-sections were transported to the University of Washington for processing, and were sanded with progressively finer grit sandpaper up to 1000 grit until the cellular structure was visible under a binocular microscope to allow accurate crossdating and ring-width measurements. The years of annual rings were then identified and marked on the samples using the methods outlined in Stokes and Smiley (1968). Cores and partial cross sections that contained only rings with clearly defined earlywood/latewood transitions were measured to 0.001-mm precision with a VelMex Unislide and Measure J2X version 4.2 software (VoorTech Consulting, Holderness, NH). We crossdated the cores and sections using a combination of 
skeleton plotting (Speer 2010) and the list method (Stokes and Smiley 1968, Speer 2010), and we used the computer program COFECHA (Holmes 1983, Grissino-Mayer 2001b) as a statistical verification of the dating and measuring.

After measurements of these cores and sections were compiled into a master chronology, we were able to crossdate samples that contained more difficult rings. We identified common patterns of narrow and wide rings as well as narrow and wide latewood in the master set of dated samples. We then located these common patterns on the more difficult sections, and in many cases we were able to identify false, missing and diffuse rings occurring during years between the identifiable patterns. Finally, these dated cores and sections were measured and verified in COFECHA. Those that were highly correlated with the chronology were incorporated into the final master chronology. Because of the high incidence of unidentifiable false rings, only $27 \%$ of the original samples could be included in the master chronology. We then dated fire scars by identifying the year, and where possible the intraring position (Dieterich and Swetnam 1984, Heyerdahl and Alvarado 2003) on samples that could be crossdated. The final step was to compute the frequency and variability of fire occurrence in each plot and across the study area using the software FHX2 version 3.2 (Grissino-Mayer 2001a).

\section{Discussion and Conclusions}

Crossdating Pinus douglasiana was challenging due to many false and diffuse rings and a small number of missing rings. However, a master chronology of 78 samples was compiled with satisfactory correlation, which shows that this species of tropical pine can be used in dendrochronological studies. This study also contributes an original master chronology of tree rings to the SMBR, which will be available to future researchers, as well as a reconstruction of the fire history in and around the Las Joyas Research Station reaching back to 1938. A master's thesis and a manuscript are currently being authored, which will both ultimately communicate the detailed results of this study.

\section{Acknowledgements}

Support for this research was provided by the International Association of Wildland Fire and the School of Environmental and Forest Sciences at the University of Washington. We would like to thank Enrique Jardel Paláez and the University of Guadalajara, Centro Universitario de la Costa Sur and the administration of the Reserva de la Biosfera Sierra de Manantlán for facilitating this research. Also, thank you to Emily Heyerdahl, Diego Perez Salicrup and Ivan Easton for their valuable guidance and for serving on Brooke Cassell's graduate committee.

\section{References}

Agee, J.K. 1993. Fire ecology of Pacific Northwest forests. Island Press, Washington, DC.

Arno, S.F. and K.M. Sneck. 1977. A method for determining fire history in coniferous forests of the mountain west. US Department of Agriculture, Forest Service, Intermountain Forest and Range Experimental Station, Ogden, UT. General Technical Report No. GTR-INT-42.

Balcázar-Medina, O.E. 2011. Patrones geoecológicos de incendios forestales en la Reserva de la Biosfera Sierra de Manantlán (Master of Science). Universidad de Guadalajara, Centro Universitario de la
Costa Sur, División de Desarrollo Regional, Departamento de Ecología y Recursos Naturales.

Copenheaver, C.A., E.A. Pokorski, J.E. Currie and M.D. Abrams. 2006. Causation of false ring formation in Pinus banksiana: A comparison of age, canopy class, climate and growth rate. Forest Ecology and Management 236(2-3): 348-355.

Dieterich, J.H. and T.W. Swetnam. 1984. Notes: Dendrochronology of a fire-scarred ponderosa pine. Forest Science 30(1): 238-247. Edmondson, J.R. 2010. The meteorological significance of false rings in eastern redcedar (Juniperus virginiana L.) from the southern Great Plains, U.S.A. Tree-Ring Research 66(1): 19-33.

Fritts, H.C. 1976. Tree rings and climate. Academic Press Inc., New York.

Grissino-Mayer, H.D. 2001a. FHX2 - Software for analyzing temporal and spatial patterns in fire regimes from tree rings. Tree-Ring Research 57(1): 115-124.

Grissino-Mayer, H.D. 2001b. Evaluating crossdating accuracy: A manual and tutorial for the computer program COFECHA. TreeRing Research 57(2): 205-221.

Heyerdahl, E.K. and E. Alvarado. 2003. Influence of climate and land use on historical surface fires in pine-oak forests, Sierra Madre Occidental, Mexico. In T.T. Veblen, W.L. Baker, G. Montenegro and T.W. Swetnam (eds.). Fire and climatic change in temperate ecosystems of the western Americas. Ecological Studies, Vol. 160. pp. 196-217. Springer, New York.

Hoffer, M.H.M. and J.C. Tardif. 2009. False rings in jack pine and black spruce trees from eastern Manitoba as indicators of dry summers. Canadian Journal of Forest Research 39(9): 1722-1736.

Holmes, R.L. 1983. Computer-assisted quality control in tree-ring dating and measurement. Tree-Ring Bulletin 43: 69-78.

Huante, P., E. Rincón and T.W. Swetnam. 1991. Dendrochronology of Abies religiosa in Michoacan, Mexico. Tree-Ring Bulletin 51: $15-28$.

[INE] Instituto Nacional de Ecología. 2000. Programa de manejo de la reserva de la Biosfera Sierra de Manantlán, México. INESEMARNAT, Mexico. Available from http://www.ine.gob.mx/publicaciones/download/181.pdf

Jardel, E. 1991. Perturbaciones naturales y antropogénicas y su influencia en la dinámica sucesional de los bosques de Las Joyas, Sierra de Manantlán, Jalisco. Tiempos de Ciencia 22: 9-26.

Jardel P., E.J., R. Ramírez-Villeda, F. Castillo-Navarro and O.E. Balcázar M. 2003. Fire management and restoration plan in the Sierra de Manantlán Biosphere Reserve, México. Proceedings: 5th Symposium on Fire and Forest Meteorology Joint with 2nd International Wildland Fire Ecology and Fire Management Congress, Coronado Springs Resort, Orlando, FL.

Jardel-Peláez, E.J., J.E. Morfín-Ríos, E. Alvarado, D. Pérez-Salicrup and J.M. Rodríguez-Gómez. (in press). Caracterizacíon, clasificacíon y mapeo de los regímenes potenciales de incendios en los ecosistemas forestales de México (Technical Report) (p. 37). Comisión Nacional Forestal.

Marchand, N. and L. Filion. 2012. False rings in the white pine (Pinus strobus) of the Outaouais Hills, Québec (Canada), as indicators of water stress. Canadian Journal of Forest Research 42(1): $12-22$.

Priya, P. and K. Bhat. 1998. False ring formation in teak (Tectona grandis Lf) and the influence of environmental factors. Forest Ecology and Management 108(3): 215-222.

Speer, J.H. 2010. Fundamentals of tree ring research. The University of Arizona Press, Tucson, AZ.

Stokes, M.A. and T.L. Smiley. 1968. An introduction to tree-ring dating. The University of Chicago Press, Chicago, IL.

Whelan, R.J. 1995. The ecology of fire. Cambridge University Press, Cambridge, New York.

Wimmer, R., G. Strumia and F. Holawe. 2000. Use of false rings in Austrian pine to reconstruct early growing season precipitation. Canadian Journal of Forest Research 30(11): 1691-1697. 